\title{
Nonstandard time wage premiums and employment effects: Evidence from an Australian natural experiment
}

One of the major themes in recent industrial relations research, and a focal point of policy debate, has been the time of work, in particular how it intersects with the non-work activities of workers. The phrases 'work-family balance' or 'work-life conflict' have been used to describe core issues involved. Significant research attention has been paid to the role of job characteristics, including long working hours and hours-related preferences. The timing of work, at non-standard hours and particularly on weekends, has been relatively understudied. Corporate policy makers meanwhile have sought to encourage firms to be more 'flexible' or 'accommodating' towards employees, and unions and public policy makers have tended towards regulation - either by banning work at certain times or above a certain number of hours within a time period, or by forcing employers to pay a premium for work in nonstandard times. Such restrictions or obligations are not new and part of the push for greater labour market flexibility over the past three decades in many countries has involved the easing or removal of such restrictions or obligations, to promote employment growth.

While movements in the opposite direction have been rare of late, an important one occurred in New South Wales (NSW), the most populous state in Australia, from 2010 to 2015. As a result of a legislatively-driven 'award modernization' process that standardized employment conditions within an industry across the country, non-standard time premiums for working Sundays in retail trade (one of the largest employing industries) rose significantly there. At the same time, no change was required in the second largest and adjacent state, Victoria. This provided the basis for an important natural experiment, comparing outcomes in the two states. Employers anticipated major employment losses; unions major gains for employees.

We examine the effects of increasing Sunday premiums on employment outcomes - number of employees, hours per employee, and the likelihood of working on Sundays - taking advantage of this natural experiment. By using Victoria as a counterfactual, and controlling for a range of state-specific factors, we isolate the effects of the rising Sunday premiums in NSW. We thus address whether there were adverse effects on employment levels in NSW, or 
on the distribution of employment through the week. We thereby consider whether regulation of working time through public policy has a valid role to play in influencing worklife conflict.

\section{Time, work and pay}

Of all resources available to us, time is the one that becomes unavoidably scarcer. While real GDP per capita grows, the number of hours in a week remains fixed. At the heart of the debate on non-standard hours premiums is how individuals, families and society value their time and choose to allocate it. The choice between wage-earning work, household work, and leisure time depends not only on preferences and needs (and that of one's family), but also on employment conditions including the wage rate. Work-life conflict results from demands placed on individuals with work and non-work roles and obligations. Interdisciplinary research has identified time-based pressure as a primary determinant of work-life conflict, pressures which include long working hours, schedule inflexibility, and shift/overtime requirements (Greenhaus \& Beutell 1985; Byron, 2005; Ford et al, 2007; Michel et al, 2010). While these studies have been concentrated in psychology and sociology, the economic aspects of when we work have been under-studied (Hamermesh, 2015). Yet the assumed growing demand for round-the-clock production and consumption - and an attendant workforce - is said to produce productivity and efficiency benefits for employers, and benefits for those workers who regard working on Sundays or evenings as no different from working on Tuesday afternoon. Some argue, for example, that more flexible working arrangements could benefit young students or dual income families who might be better able to work around study or family commitments (Deloitte Access Economics, 2015: 16-20).

Descriptive Australian survey data show that younger and/or single employees in low-skill occupations in casual employment (akin to 'zero-hours' contracts) are more likely to work weekends or evenings (Daly, 2014). It is unclear whether this reflects the preferences of these individuals, or these individuals are less able to 'buy' greater amenity - namely, work during standard daylight hours (Hamermesh, 1999a; Hamermesh \& Stancanelli, 2014; Scheffel, 2011). A number of Australian studies have shown working time preferences continue to follow societal norms of standard weekday working hours. Baker et al (2003) used matched 
samples of Australian standard and shift workers to show both groups valued social time on evenings and weekends equally. Hosking and Western (2008) showed weekend work was significantly associated with work-family conflict for fathers, while evidence from the Australian Work and Life Index (AWALI) indicated that working Sundays in particular was associated with higher levels of work-life interference (Skinner et al, 2012; Skinner \& Pocock, 2014). Contrary to claims that Sundays are no longer privileged, recent Australian studies also showed that Sunday remained a day for family and civic activities, more so than Saturday or any weekday (Craig \& Brown, 2014; Bittman, 2005).

This greater value attached to Sundays, and weekends generally, underlie the rationale for wage premiums in theories both of competitive labour markets and of institutionally based wage determination. Traditional economic theory argues that 'compensating wages' exist in a competitive labour market to compensate employees for onerous working conditions, including work at valuable social times; in this model, employees trade off wages against the cost of the dis-amenity (Rosen, 1986). The theory predicts that demand for labour at undesirable working hours will require premium rates to induce sufficient workers to work at those times, and that demand for more amenable working times is income-elastic (Hamermesh, 1999a, 1999b).

While weekend work, and non-standard working hours generally, are obvious candidates for studying compensatory wages, they have been less studied than many other job characteristics, and there is an overall paucity of research on the link between compensatory wages and job attributes (Fernandez \& Rosa, 2009: 196). Earlier studies focused on job characteristics including job stress (French \& Dunlap, 1998; Groot \& Maassen van den Brink, 1999), and risk of injury (Hamermesh, 1999b; Hersch, 1998). In Australia, Borland and Suen (1990) for example showed that wage premiums existed where the risk of fatal accident was higher. Studies of wage differentials for undesirable working hours are complicated by heterogeneous worker preferences (there might be enough workers who prefer non-standard work such that premiums for weekend work would be unnecessary). A number of US studies have shown, however, that the decision to work non-standard hours results from the premium incentives and not worker preferences (Kostiuk, 1990; Lanfranchi et al, 2002). The undesirability of weekend and evening work is also indicated by the 
demographic profile of these workers, with lesser educated, younger and minority employees (such as immigrants) with lower bargaining power and therefore more likely to work outside standard hours, and within low-skill occupations (Hamermesh \& Stancanelli, 2014; Scheffel, 2011; Daly, 2014). Furthermore, declines in evening and night work in the US have been explained by workers (particularly those at the upper end of the earnings distribution) using increased earnings to 'buy' more work amenity - namely, to work during standard daylight hours (Hamermesh, 1999a; 1999b). Together these findings suggest that there are strong preferences for standard working hours, and that premiums are needed to induce voluntary labour supply at undesirable hours.

There have been limited studies on the timing of production and labour demand. In perhaps the only study of its kind, Cardoso et al. (2012) analysed data on 964 Portuguese firms across all industries, examining hour-by-hour employment through the week. They showed that employers were able to substitute work at one time of day in the week for another in response to different wage rates. The authors concluded that wage premiums could be an effective tool for social policy on working time.

These studies assumed that wage premiums are generated by a competitive market. However, theories of the competitive market, including compensatory wage differentials, remain contested, and struggle to explain the large wage gaps across industry, occupation and gender in Australia (Preston, 1997). In contrast, the industrial relations and sociology literature argues that premiums for non-standard work hours are embedded in social norms and institutions. In Australia, the notion of 'normal' hours of work was first formalised in 1909 by the Commonwealth Court of Conciliation and Arbitration, which awarded a time and a half premium ('penalty payment') for:

All the time of work on the seventh day in any week, or an official holiday, and all time of work done in excess of the ordinary shift during each day of twenty hours

Barrier Branch of the Amalgamated Miners Association v. Broken Hill Pty Ltd (1909, cited in Jones, 1981)

It aimed to deter employers from impinging on workers' limited leisure opportunities. Various subsequent cases dealt with such issues (Department of Education, Employment and 
Workplace Relations, 2012:4-5). In 1981, the community standard, drawn from diverse areas of employment, was stated as including: a standard Monday to Friday 40 hour work week, with a time and a half Saturday rate and double time Sunday rate (Department of Industrial Relations, 1981, cited in Dawkins, 1986). Not long afterwards, following a union campaign in manufacturing, the 'standard' working week was set at 38 hours (Department of Education, Employment and Workplace Relations, 2008).

These community standards remain robust, with 69 per cent of Australian employees in 2012 still reporting that they work only weekdays (ABS, 2012a). The proportion of employees working some time on weekends rose from around 25 per cent in 1997 to 31 per cent in 2012 (Bittman, 2005; ABS, 2012a). The 2014 AWALI survey showed that of the 45 per cent of employees who receive any premiums (called 'penalty rates' in Australia), 38 per cent indicated that they would not continue working unsocial hours if premiums were removed (Daly, 2014:17).

Data on the retail industry, the focus of this article, suggests an even stronger role for premiums. The AWALI survey indicates that 37 per cent of retail workers worked on weekends only, with a further 15 per cent working evenings and weekends (Daly, 2014). More than half (57\%) of retail employees working 'anti-social' ours received premiums, and of these, over half of retail workers (52\%) said that they would not continue working weekends or evenings without the inducement of penalty rates.

Contemporary debate in Australia on Sunday premiums addresses two issues. The first is whether Sundays are indeed valued more highly than Saturdays and weekdays by workers, with some advocates suggesting the '24/7' economy renders them an accident of history (Turnbull in Bourke, 2015). However, the studies mentioned above suggest that people still reserve Sundays for family, social and civic activities, and that working on Sundays induces work-family conflict. The second issue is to what extent compensating employees for working on Sundays has an adverse effect on employment outcomes. This latter issue is the core focus of the remainder of this article.

The analysis that follows measures the effect of increased Sunday premiums on employment in the NSW retail industry. A challenge with identifying such an effect is disentangling it from those arising from a range of other social and economic phenomenon. These could 
include the deregulation of trading hours, shifts in the business cycle, and changes in labour demand in other industries - each of these could have an independent effect on employment, which would be easy to conflate with the effect that premiums might have. In order to isolate the effect of higher Sunday premiums, the research uses a quasi-natural experimental framework, which exploits the exogenous changes in NSW Sunday premiums during the award modernization process. The next section details these policy changes, and then an empirical model is laid out.

\section{Institutional background}

An 'award' in Australia is a legally binding decision of an arbitral tribunal that sets minimum pay and conditions in an industry. Nationally, around 19 per cent of Australian employees in 2014 had their minimum pay and conditions determined by an award (they are 'awardreliant'), including 29 per cent in the retail industry (ABS, 2014b). Another large group have their pay set above the award rate but it is still determined by reference to it. The number of firms for whom this is the main method of setting pay (25 per cent) is similar to the number of firms who use exactly the award rate (Yuen et al, 2015). Both these numbers decrease as employer size raises, the former more so. In total, 54 per cent of Australian retail employees have their pay set or guided in some way by the applicable award rate of pay (Wright $\&$ Buchanan, 2013). Many retail employees - 36 per cent, the second highest of any industryare employed on a casual basis, meaning they have no leave entitlements and their contract of employment lasts only for the current shift, making it easier for employers to adjust both the number of jobs and the number of hours worked. Casual employees tend to have higher award reliance — nationally, 45 per cent of casuals are on award rates, compared to 18 per cent of non-casuals - and this is one reason why award reliance is higher in retail than most other industries (ABS, 2014a).

Until the 2000s, award rates could differ between states. The 'award modernization' process introduced new national minimum standards for employment pay and conditions across different industries and occupations, in place of multitudinous state-based awards. In the retail industry, these conditions included a 100 per cent ('double time') Sunday premium in the new General Retail Award. This new national standard enabled a quasi-experiment between award-reliant retail employees in NSW and Victoria - Victorian employees saw no 
change to their Sunday premiums, whereas NSW employees moved from receiving a 50 per cent Sunday premium ('time and a half') to 100 per cent.

Award modernization in retail included transitional arrangements, in place from 1 July 2010 to 1 July 2014. Sunday premiums increased incrementally, by 10 percentage points, with effect each year from 1 July 2010 to 1 July 2014 (Table 1), but were announced on December 19, 2008. Changes in other entitlements were relatively small or zero. As NSW trading hours were effectively deregulated by 1999, (National Competition Council, 1999; New South Wales Government, 2007) trading hour regulations between NSW and Victoria were substantially the same from the year 2000 onwards. Our analysis uses data from between 2001 and 2015, and is therefore unaffected by either changes in trading hours, or the national introduction of the Goods and Services Tax in July 2000. 


\section{Data and Methodology}

We investigate the announcement and implementation of increases in the Sunday premiums in the NSW retail industry, and their effects on the following:

- Total number of workers employed;

- Hours worked per employee; and

- The probability of working on Sundays in the NSW retail industry.

A challenge lies in ascertaining what would have happened in the NSW retail industry in the counterfactual scenario, that is, in the absence of the policy change. In this case, there is a proposed control group for NSW retail employees - Victorian retail employees. Victorian retail was unaffected by the changes in Sunday premiums, and as shown below, exhibits similar employment trends to NSW retail. We cannot include other states in the analysis, as each state had a different suite of changes to their award conditions. The analysis uses a difference-in-difference, quasi-experimental framework to exploit the exogenous increases in Sunday premiums in the NSW retail industry, compared to fixed rates in the Victorian retail industry. The differencing of the two states' outcomes removes biases from simple comparisons over time in NSW alone that may be due to time trends unrelated to the change in Sunday premiums (Imbens \& Wooldridge, 2009:67).

The analysis is based on two data sources:

1. published quarterly aggregate data from the Australian Bureau of Statistics (ABS) on the number of retail industry workers and hours per employee in New South Wales and Victoria, are the main source of data for this study; and

2. longitudinal data from the Household, Income and Labour Dynamics in Australia (HILDA) survey on individuals working in the retail industry in both New South Wales and Victoria. HILDA is an annual longitudinal survey of over 13,000 individuals that commenced in 2001 (and was available up to 2013 only). The HILDA dataset includes data on demographic characteristics, hours of work, employment characteristics and whether individuals usually work on Sundays. The HILDA survey fieldwork is undertaken from late July or August each year, with about 80 per cent of the sample collected in September and October between 2001 and 2010, and in August and September from 2011 onwards.

Data on the total number of workers are derived from the ABS's Labour Force Survey. The sample is based on the 2011 Census of Population and Housing, and data collected from 
about 26,000 households. The survey is collected each month starting on the first Sunday after the $5^{\text {th }}$ of each month, with households being surveyed in the first instance face-to-face, and henceforth by phone. Each month, one-eighth of the sample is rotated out and replaced. The survey collects a range of employment data, including labour force status, demographics, and hours of employment; every third month, occupation and industry data are obtained. The Labour Force Survey also derives the hours per worker by dividing the number of aggregate hours by the number of workers (it does not survey individual-level hours directly). We replicate this process for the NSW and Victorian retail industry.

The annual changes in employment (employed persons as well as hours per employee) are presented for both states in Table 2. The average annual change in the number of employees for the years 2001 to 2008 (up to the announcement of increases in penalty rates) in NSW was 3.9 and 1.9 percent in for Victoria. From 2008 to 2014, the average annual change was 2.0 percent in NSW and 1.8 percent in Victoria. Similarly, hours per employee fell on average 0.9 percent in the years post-announcement in NSW, compared to no change in Victoria. These changes may be owing to the increases in NSW penalty rates, however this raw data ignores potentially significant factors which are addressed in the empirical model which follows. 
Use of data on total employees and hours per employee allows for assessment of the effects of the changes in Sunday premiums on employment. As a check on this analysis, we use individual-level data to measure whether employers shifted the distribution of employment away from Sunday to other days of the week. A reduction in employment as a result of the higher premiums could only have occurred if Sunday employment fell. It is possible that a reduction in employment has occurred but it is so small as to be not statistically significant, but if we also find that there has been no reduction in the likelihood of a retail employee working on Sunday, then it would seem very unlikely that there has been any employment effect arising from higher Sunday premiums in NSW. Conversely, if there is both a significant reduction in total employment and a significant reduction in Sunday employment, then it is likely that there has been some employment effect from the change in Sunday premiums. Other combinations of findings would give us reason to be cautious: a significant and consistent fall in total employment, but no significant reduction in Sunday employment, would raise questions as to whether some other, unobserved factor (other than Sunday premiums) is at work. A significant reduction in Sunday employment with no accompanying loss in total employment would raise questions as to whether losses in Sunday employment have been offset elsewhere.

Any shift in Sunday employment implies a change in Sunday wages relative to the wages on other days, but data limitations make it challenging to estimate the extent of this intermediate step. A difficulty arises in observing hourly wages through employee-level self-reported data: the ABS uses more reliable data collected from employers (not employees) in the Survey of Employee Earnings and Hours (EEH), but does not collect or publish hourly wage data from the LFS. Data from the more reliable EEH survey showed a higher wage increase amongst retail workers in NSW than in Victoria between May 2010 (before the first increase) and May 2012 (after the second), but these data could not be limited to employees working Sundays and was not available in other years (ABS, 2012b). As the EEH does not provide aggregate state-and-industry-level data on the distribution of wages throughout the week, we instead use individual-level data to look for indications of a wage effect induced by the reform.

Table 3 describes the hourly wage data from HILDA on retail employees in the two states before and after the announcement of the policy change ${ }^{1}$. We present both mean and median

\footnotetext{
${ }^{1}$ We present announcement date effects in order to align with those found in our later results, which found that the effects of the policy change were strongest following announcement rather than implementation date.
} 
values, which differ substantially due to the small sample and high variability in the data. The first two data columns show that NSW employees working on Sundays, on average, had wages 2.72 percent lower than their counterparts in Victoria before the announced increase in Sunday rates. After the announcement, NSW wages for Sunday workers were on average 1.57 percent higher - this constitutes a 4.29 percentage point turnaround. Using median values, the increase was 16.92 percentage points. By comparison, NSW employees not working on Sundays did not experience a commensurate increase in wage premiums (using either mean or median values). Table 3 also shows that a more formal difference-indifference model $^{2}$ of these wage effects produced results as expected - a large and positive announcement effect $(9.5 \%)$ on the hourly wages of Sunday workers in NSW, but shown to be statistically insignificant due to the small sample size and high variability in wages data; for non-Sunday workers in NSW, a small (1.0\%) and statistically insignificant effect.

---TABLE 3 ABOUT HERE ---

On balance, it appears likely that wages for Sunday retail workers in NSW did rise by more than wages for their Victorian equivalents after the increase in Sunday premiums, but we are cautious in being conclusive on this issue. While the causal chain from official premium, to wages paid, to changes in employment is of interest, it is not possible here to precisely investigate each link of the chain; our interest remains on the ultimate employment effects.

\footnotetext{
${ }^{2} \mathrm{We}$ implemented basic difference-in-difference models of the logarithm of hourly wages, including year and state dummy variables, and comparing NSW to Victorian retail employees..
} 
Table 4 shows summary statistics from pooled HILDA data on workers in NSW and Victorian retail workers. The 'before' data were collected in 2007 to 2008 . The 'after' data were collected from 2009 to 2013 . The sample of retail workers includes 826 distinct individuals in NSW and 746 in Victoria, totalling 3714 observations over the seven-year period.

Overall the data in Table 4 show majorities of retail workers are female, live in metropolitan areas, have completed Year 12 high school education, and work part-time for large employers. In addition, significant proportions are married, work as casuals - that is, without holiday or sick leave, and without guaranteed employment beyond the current shift. Many are under the age of 25 .

The difference-in-difference regression framework allows for controls on the observed differences between the NSW and Victorian retail workers. The table also shows that there are some clear observed differences between retail workers in the two respective states before the premium changes. First, a greater proportion of respondents in NSW were female, who may preference non-standard hours differently to males. Second, a higher proportion of retail workers in NSW were under the age of 25 (44.7\% compared to $38.6 \%$ in Victoria). Third, a higher proportion of NSW retail workers were employed on a part-time or casual basis. These are important controls, as part time of casual workers may be more likely to work on weekends, and so we consider whether their employment is more sensitive to changes in labour demand as a result of changes in premiums.

The proportion of respondents in NSW who reported working on Sundays fell slightly from 25.3 to 23.7 per cent, compared to a similar decline in Victoria (falling from 22.7 to 20.6 per cent). The analysis that follows includes important individual controls that may have had independent effects on employment in NSW and Victoria. 
-- TABLE 4 ABOUT HERE-- 


\section{Empirical model}

Our quasi-experimental approach, the difference-in-difference regression model, compares the outcomes of a 'treatment' group to that of a counterfactual 'control' group. Here, the treatment refers to the increase in Sunday award premiums in the NSW retail industry. The treatment group is retail workers in NSW, while the control group is retail workers in Victoria. There are also multiple treatments - rather than there being a single policy intervention, the transitional arrangements inscribed five annual increases in NSW, beginning on 1 July, 2010. However, the higher Sunday penalty rates were announced on December 19, 2008, almost two full years before their implementation. It is possible that retail employers reacted to the announcement of higher Sunday wages, and adjusted their employee numbers or hours per employee accordingly. In this case, we might observe a significant decline in employment following the announcement in 2008, together with a distribution of employment away from Sundays, although our data does not allow us to observe solely Sunday working hours

The evaluation period consequently measures the outcomes between February 2009 and February 2015 (the 'after' period following announcement and implementation), compared to the period between February 2001 and November 2008 (the 'before' period). The 'before' period is chosen to maximize the sample period before the policy intervention following deregulation of Sunday trading hours in both Victoria (1996) and NSW (in practice by 1999, according to the National Competition Council). It also excludes the introduction of the nationwide Goods and Services Tax, Australia's main consumption tax, in July 2000.

The key assumption for the model is that employment trends would be the same for both states in the absence of the reform (and are not systematically related to unobserved factors). In the following analysis, the regression form of the difference-in-difference model is used to allow for multiple treatments (on the one treatment group), state-specific controls, and a state-specific trend. The empirical model is specified as follows:

$$
y_{s t}=\alpha_{s}+\gamma_{t}+\tau_{s t}+\sum_{k=1}^{2} \beta_{-k} D_{s,-k}+\sum_{k=1}^{6} \beta_{k} D_{s, k}+\boldsymbol{\delta} \boldsymbol{X}_{s t}+\varepsilon_{s t}
$$


In equation (1), $\alpha_{s}$ represents state-specific effects, $\gamma_{t}$ periodic (quarterly) time effects, and $\tau_{s t}$ represents a state-specific time trend. Controls for observed state-specific factors are contained in the vector $\boldsymbol{X}_{\boldsymbol{s}}$, and includes time-varying, state-level unemployment rates, employment to population ratios, and state retail sales. These variables are particularly important for controlling for potential state level effects of the global economic crisis of 2008 and 2009. Large fluctuations in retail employment were significantly explained by these state-level economic factors ${ }^{3}$, with the incremental effects of the higher penalty rates subsequently estimated more precisely. The effect of the increase in Sunday premiums is captured by the parameters $\beta_{k}$ in the second sum $(\mathrm{k}=1,2,3,4,5,6)$ representing the effects following the announcement of changes, and also each of the increases). These are the coefficients on the indicator variables $D_{s k}$, which take a value of one if the observation took place in NSW in a period after the announced increases, and zero otherwise.

The outcome variable $y_{s t}$ refers to two distinct employment outcomes: the logarithm of total number of retail employees, and the logarithm of number of hours worked per employee in retail, in state $s$ at time $t$. Quarterly aggregate time-series data is used. Ordinary least squares regression is used to estimate equation (1). Newey-West heteroscedasticity and autocorrelation consistent (HAC) standard errors have been used to mitigate in particular concerns raised by Bertrand et al (2004) regarding the effect of serial correlation on difference-in-difference models.

The critical challenge is identification. The key identifying assumption underlying the empirical analysis is that NSW and Victoria shared common employment trends prior to the policy changes. Error! Reference source not found. 1 shows the total number of retail workers in NSW and Victoria from 2001 to 2008, with a fitted trend line. It shows that over the period, the two states have moved broadly in parallel, despite considerable variability induced by the financial crisis from 2007.

\footnotetext{
${ }^{3}$ A model based on time effects and state-level factors only produced an adjusted R-squared of 0.925
} 
A formal test of this identifying assumption takes the form of a 'placebo test', following the specification used in Autor (2003). In equation (1), the first sum refers to the 'lead' effects in the two years before the announcement of higher Sunday rates. The test is designed to detect spurious treatment effects where there should be none, and a finding of no significant effects in the years prior to the policy announcement lends support to the causal interpretation of results (Angrist \& Pischke, 2009; Autor, 2003). Finally, the addition of state-specific time trend allows for the possibility that pre-existing employment trends were important to subsequent employment outcomes, and acts as a further robustness check on the identification strategy (Angrist \& Pischke, 2009; Besley \& Burgess, 2004).

A second model uses individual-level data and measures changes in the distribution of employment away from Sunday. This model acts as an important check on the results of the model in equation (1). The outcome measure in this case is binary variable $y_{i s t}$ indicating whether an individual $i$ in state $s$ in year $t$ reports working on Sundays. A linear probability model is used to estimate equation (2) using individual-level panel data (probit models gave similar results, and results are available from the authors). Heteroskedastic-consistent, clustered-by-individual standard errors were used. 


$$
y_{i s t}=\alpha_{s}+\gamma_{t}+\sum_{k=1}^{4} \beta_{k} D_{s k}+\boldsymbol{\delta} \boldsymbol{X}_{\text {ist }}+\varepsilon_{i s t}
$$

In this case, individual-level controls captured by $\boldsymbol{X}_{\text {ist }}$ includes gender, marital status, presence of dependent children, part-time and casual employment status, education level, binary youth indicator, union member status, and employer size. The evaluation 'before period' relates to data collected between 2007 and 2008, while the 'after period' follows announcement and implementation of the higher Sunday rates, and includes 2009 to 2013. Note that the individual level, annual data were only available to 2013 (with data collected mostly in August and September), and consequently only the first four increases in Sunday premiums are evaluated. In addition, we do not observe hours worked on Sunday, so are only able to capture employees who ceased working on Sundays, and not reductions in Sunday hours.

A causal interpretation of our results assumes that there are no systematic differences between retail employees in NSW and Victoria. Aside from controlling for observed differences between the two groups, a variation on the placebo test was also used to check the individual-level results for Sunday employment, to ensure we are not reporting spurious effects. Specifically, the model was replicated estimating the effects of working on Saturday - there were no changes to Saturday wage rates in NSW, and Saturday penalty rates in Victoria fell slightly (on average from $33 \%$ to $25 \%$ over five years). There should be no change then in the likelihood of NSW retail employees working on Saturdays. The estimated placebo effect in NSW should be insignificant, or slightly negative if the fall in Victorian Saturday rates had any effect. 


\section{Results}

\section{Employment}

We use two measures of employment: the number of jobs, and the number of hours worked per worker. Both measures are relevant to the policy question. In particular, if the number of jobs remains unchanged but the hours per worker decreases (increases) in response to a rise (fall) in Sunday premiums, it likely means that the same number of employees are offsetting the gain (loss) in hourly pay by each working fewer (more) hours. This in turn influences whether, and in what form, there is a transfer in welfare between employees and employers. For example, if the same number of employees work more (fewer) hours for the same weekly income, and have less (more) leisure, while profits necessarily increase (decrease), there is an unambiguous shift in welfare from (to) employees to (from) employers.

The results of the regression analysis of employment effects are presented in Table 5. Figures 2 and 3 provide graphical illustrations of the employment effects arising from the increase in Sunday wage premiums, on the total number employed and hours per worker, respectively. These figures not only give insight into the dynamics of how the rollout of higher Sunday rates affected employment, but also show that in the lead up to the announcement (pre-2008), there were no spurious effects detected.

In table 5, the key results are the coefficient estimates on the date variables. The treatment effects are identified in the years 2008 (following announcement) to 2014 (following the final increase in Sunday rates). In addition to testing the null hypotheses - that the annual effects following the announcement and rollout of Sunday rate increases were each statistically no different from zero- tests were also conducted on the sum of the treatment coefficients This determines whether the cumulative effect of the five premium increases from their announcement onwards, was statistically different from zero. The coefficients on the years 2006 and 2007 form a placebo test of our identification strategy, and are discussed further below. Regression results in Table 5 are reported at the 5\% significance level. 
---TABLE 5 ABOUT HERE ---

---FIGURE 2ABOUT HERE ---

---FIGURE 3 ABOUT HERE --- 
The results in Table 5 and Figure 2 show no consistent effects on the number of jobs. There appeared to be no significant announcement effect in the period between the announcement and implementation of changes, and only a weakly significant 5.1 per cent increase in the number employed in 2011. As shown in Figure 2, the magnitudes and directions of the effects varied and were mostly statistically insignificant. A test on the sum of the treatment coefficients taken from announcement date showed that the cumulative effect between 2008 and 2014 was weakly significant and negative ( $p$-value=0.079). Taken from implementation date, the cumulative effect was found to be statistically insignificant ( $p$-value=0.176).

The results for hours per worker (Table 5 and Figure 3) suggested a significant announcement year effect, with a significant drop of 5.2 percent. The implication could be that many employers paid more attention to news about the existence and size of the changes than about their formal dates of effect. There was no significant change in hours per worker in other years, however the test on the cumulative effect taken from announcement date was statistically significant and negative ( $\mathrm{p}$-value $=0.027$ ). Taken from implementation date however, the cumulative effect was statistically insignificant ( $\mathrm{p}$-value $=0.18$ ). Figure 3 also clearly shows that the impact on hours per worker appeared to be less variable. However, this may be because much of the heterogeneity in workers' hours is lost by deriving hours per worker from aggregate figures, rather than surveying individuals directly.

The negative announcement effect on hours per worker, combined with the lack of effect on number of workers, led to an overall weakly significant and negative effect on total hours worked (not shown, but available upon request).

The state-level controls for employment conditions and aggregate demand, including employment-to-population ratios, unemployment rates, and retail sales, were jointly significant. State employment-to-population ratios were highly significant proxies for available employment opportunities. The models also found large and positive state-effects on hours per worker (with a weakly significant result for number of jobs). The state effects captures unobserved but time-invariant differences between NSW and Victoria, and indicate that employment is generally higher in NSW (as illustrated earlier in Figure 1).

A formal test of our identifying assumptions, drawing on Autor (2003), is provided using the estimation of 'lead effects' in the two years (2006 and 2007) preceding the announcement of higher Sunday rates. In Table 5 (and Figures 2 to 3), the lead effects are both close to zero and statistically insignificant, as expected. This absence of spurious lead effects supports the 
causal interpretation of our results. An additional robustness check, suggested by Besley and Burgess (2004), entails the inclusion of the state-specific trend in our empirical model. As shown in Table 5, this inclusion of a state-specific trend did not suggest a significant role for pre-existing state employment trends.

Overall, the results for employment effects suggest that the predominant response to the announcement of higher Sunday penalty rates was a downward adjustment in hours per worker and consequently total employee hours in anticipation of their rollout. There was however, no clear evidence of an effect on the total number of jobs. Taken from announcement date, the impact on job losses was weakly significant and negative; the impact on hours per employee was found to be significant. Taken from implementation date onwards however, the effects were in both cases statistically insignificant. The difference in these cumulative results (post-announcement versus post-implementation) suggests that despite the five-year period for implementation, adjustments were made early in the transition. This is despite the high levels of casual employment which allow employers to change employee hours at a shift's notice.

It is clear that the effect on the number of jobs, if it exists at all, is much weaker than the effect on the number of hours worked per worker. That is most, perhaps all, of the adjustment is in the form of fewer hours being worked at higher rates of pay, rather than fewer people in jobs. This is unsurprising, given the dominance of part-time and casual employment in the retail industry. In fact, because reducing hours is usually cheaper than layoffs, adjustment via hours can also occur among full-time, permanent workers, at least where they are rostered to work overtime on a Sunday (and their overtime hours can be cut). That said, a resistance point is reached if workers are already on standard full-time hours: they will strongly resist being converted to part-time hours, and retrenching full-timers due to a change in one day's wages would be needlessly expensive. So the high rate of part-time, casual work in the industry especially encourages adjustment through hours, not jobs.

\section{Working on Sundays}

As a check on to these findings on the number of jobs and hours per worker, we investigate whether there was a shift in employment away from Sundays - it is possible that NSW employers did not simply reduce staff and/or working hours, but rather redistributed them away from Sunday. 
Aggregate data on working time arrangements across Australia in 2006, 2009 and 2012 are first presented in Figures 4 and 5. The data relates to employees across all industries. They show that 9 per cent of males, and 8 per cent of females, usually worked on Sundays; these figures rose slightly in the 2009 survey, and fell again in 2012. This pattern was consistent for Saturdays as well - about 18 per cent of males and 13 per cent of females report usually working on Saturdays. This national data shows some stability in the incidence of weekend work, however is not available separately for the NSW and Victorian retail industries. 
As was shown in Table 4, about 24 per cent of the sample of NSW retail employees in the HILDA sample reported usually working on Sundays, compared to about 21 per cent of Victorian retail employees. The regression results in Table 6 show the change in the probability of working on Sundays following the announcement of higher Sunday wage rates between 2009 and 2013. The effect is estimated using a linear probability model, and can be interpreted as follows: the coefficients indicate whether the probability of Sunday employment fell following the announcement and rollout of the Sunday wage rate increases. The results are presented without additional controls (Model 1); with controls for demographic differences between employees in the two states (Model 2); and with controls for workplace differences (Model 3). These controls are important because, as was shown in Table 4, retail employees in NSW differed from those in Victoria in observed attributes. These attributes could have an independent effect on whether an individual works on Sundays, and are controlled for in the analysis.

The results ${ }^{4}$ show that without any controls (Model 1), the increases in Sunday premiums led to a significant negative effect only in 2011, with no significant effects in any of the other years. Overall, the point estimates showed effects of varying direction magnitude, and were generally insignificant.

Model 2 shows the results after controlling for important demographic differences (particularly for being under the age of 25). The estimated effects of the premium changes are virtually the same as Model 1. Model 2 indicates that those under the age of 25are significantly more likely to work on Sundays.

The final model (Model 3) includes controls for the individual's employment arrangements namely whether they worked in a large enterprise, or were a union member ${ }^{5}$. With the addition of these controls, no negative effect in 2011 could be identified, and a weakly positive effect was found following the premium increase in 2012. Across Models 1 to 3, the sum of the treatment dummy variables was not statistically different from zero, indicating

\footnotetext{
${ }^{4}$ Estimates from a linear probability model are given. Partial effects from a probit model were very similar, and are available upon request.

${ }^{5}$ It should be noted that while Table 4 indicated differences between states in the proportion of part-time and casual employees, these variables were excluded in Model 3 to allow for the possibility that the policy change might affect Sunday employment through the employment of more part-time and casual employees. The inclusion of these variables did not materially change the coefficients on the policy-date variables; rather, their inclusion acts to reduce the size of the coefficient on "Less than 25 years old", reflecting the greater propensity of younger workers to be employed part-time or casually.
} 
that the premium increases had no cumulative effects on the likelihood of working on Sundays.

-- TABLE 6 ABOUT HERE-- 
We test the identifying assumptions of our empirical strategy by re-estimating the model for the likelihood of working on Saturdays. As there were no changes to Saturday wage rates in NSW, there should be no change in the likelihood of NSW retail employees working on Saturdays, and the estimated placebo effect in NSW should be small and insignificant. The results in the last two columns of Table 6 show that, as expected, there were no significant effects in any of the individual years. In addition, the test on the cumulative impact also found no significant effects. This supports our empirical model of changes in Sunday employment.

These results using individual-level data show that employees were not less likely to work on Sundays as a result of higher Sunday wage rates. Taken together with the results on the number of jobs and hours per worker, the analysis concludes that while hours per worker fell, employers did not reduce the number of workers, nor remove Sunday employees from their Sunday shifts. The most likely explanation is that Sunday hours for existing Sunday employees (and potentially hours on other days of the week) were reduced in response to the announcement of higher Sunday wages. We are unable to confirm this with certainty however, as data on hours of employment by day-of-the-week is unavailable.

It is important to acknowledge some limitations of the analysis. Due to the nature of available data, it is impossible to isolate the effect of the policy change on those most directly affected by it - award reliant retail employees whose wages were directly determined by the award rates. Unpublished data from the ABS' Survey of Employee Earnings and Hours (a survey of 8000 employers nationally) suggests that since the introduction of modern awards, the number of award reliant employees - those paid exactly the award rate - has risen steadily from around 64,300 to 97,900 (or 21.8 to $28.3 \%$ of all employees) in NSW. In Victoria, the number increased from 53,400 to 94,100 (from 24.4 to $31.1 \%$ of all employees), as shown in Figure 6. (These numbers exclude those whose pay or conditions are influenced by, but not exactly on, the award.)

The empirical models set out above measure changes in the number of workers, hours per worker, and the probability of working on Sunday, across all employees, and not solely those who are award reliant. While this may be regarded as less precise, it is also appropriate and important because Australia's methods of wage determination are complex and not 
independent of one another. Consequently, changes in award conditions typically have extended impacts on employees on over-awards and covered by collective and even individual agreements. Investigation of all employees, and not just those who are awardreliant, is a more complete way of evaluating the employment effects of the policy change.

--- FIGURE 6 ABOUT HERE ---

The analysis is also unable to distinguish between the effects of the changes in Sunday premiums and other, smaller, changes that occurred as part of the transitional arrangements of the award modernization process. As described in Table 1, casual loadings increased slightly in NSW from $15 \%$ to $25 \%$ - 2 percentage points annually; and, Victorian Saturday premiums decreased, on average across the award classifications, from the equivalent of about $33 \%$ to $25 \%$ - about 1.6 percentage points per annum. Consequently, employment effects identified in the analysis may conflate the impact of the higher Sunday premiums and these two other changes. The three changes - higher NSW casual loadings, lower Saturday premiums in Victoria, and higher Sunday premiums in NSW, were phased in over the same five-year period. These two changes (higher NSW casual loadings, and lower Victorian Saturday loadings) act in the same direction to potentially overstate the effects of the changes in NSW Sunday premiums; therefore, the results can be considered as an upper-bound estimate. It should also be remarked however that the magnitude of the change in the Sunday premiums (10 percentage points each year) was far larger than the other changes. 
Collectively, the results suggest that following the announcement of higher Sunday wage premiums, the principal adjustment channel used by employers was hours per employee, rather than employee numbers. The results indicate that there were significant reduction of hours per employee, concentrated in the period following the announcement date in 2008. This compares to - at best - weakly significant effects on the total number of employees in response to higher Sunday penalty rates. The results for effects on hours per employee should be regarded with caution however, as there was no commensurate decline in Sunday employment, nor were there negative effects found across the entire period from announcement through implementation.

\section{Discussion and Conclusion}

Following announced increases in Sunday wage premia in NSW's retail industry, we found no effects on the number of employees, and significant negative effects on hours per worker, The adjustments to employee hours were made almost immediately following the policy announcement, with no significant effects found in the period following implementation for either number of employees or hours per employees, implying many employers pay more attention to news about the existence and size of a premium increase than about their timing. These results held, taking into account state-specific economic conditions, including total and youth employment conditions, industry demand, and state-specific employment trends.

A number of explanations for these weak employment effects following implementation have been considered. First is the possibility of substitution effects - either substitution away from Sunday employment, or substitution between employee categories (eg younger for older employees, or non award-reliant for award-reliant employees). We have examined these substitution effects where ever possible. Rich data on individual retail employees, in particular whether they worked on Sundays, was used to investigate this potential distribution of employment away from Sundays and/or towards younger workers. The results showed that the cumulative effect on Sunday employment was not statistically different from zero; yearto-year, the effects were also found to be statistically insignificant and inconsistent. However, it is possible that rather than reduce the number of Sunday workers, employers instead 
reduced Sunday hours for existing workers, an outcome which we cannot verify given data limitations.

With regard to younger versus older workers, our analysis of junior workers (available on request) showed that while there was a positive effect amongst junior workers, this was the case for only one year (2012), not consistently over the period of increasing premiums. There was also no commensurate decline in non-junior employees working on Sundays. It is likely that other factors are motivating these preferences for deploying junior employees on Sundays.

We are unable to examine the effects arising from the substitution of non-award-reliant employees in place of award-reliant employees, due to both the lack of data and the interdependence of wage-setting methods. However, Buchanan \& Wright (2013:17) found that 75 percent of retail employers used award-based pay-setting arrangements, such that it is unlikely that a large effect would result from employers drawing on workers unaffected by the rise in Sunday rates.

It is also possible that employment effects were concentrated amongst employees of small businesses, who are not well represented in the survey data. The estimated effects on small business employees (available upon request) were imprecise as expected, but did not show systematically large and negative point estimates.

Finally, we were unable to examine one key hypothesis for the resulting weak employment effects: the ability of employers to pass on higher labour costs to the consumer. There being no business-level dataset on operational performance, we are unable to examine this possibility.

Overall, the research showed that while the number of employed retail workers was unaffected, it was more likely that there was a negative effect on hours per worker. The immediate implication is that, ceteris paribus, the same number of employees worked fewer hours as Sunday premiums rose. This supports the notion that in an industry dominated by casual and part-time employment, adjustment to employment occurs via flexibility in hours, and not in the number of employees. This interpretation of the results suggests that the elasticity of aggregate labour demand in response to Sunday wage changes is close to zero if demand is measured by the number of jobs, and potentially negative if measured by number of hours per employee. It suggests that increasing Sunday premiums has little effect on the 
number of employees or on Sunday employment; however, they do have the effect of providing compensation for those people who work on Sundays.

What, then, are the policy implications? In the case recently heard by the Australian tribunal, the Fair Work Commission, an application was made and granted to significantly cut Sunday wage premiums in the retail industry. Such a decrease will most likely result in virtually the same number of employees working longer hours for what would be (assuming an elasticity of Sunday labour demand with respect to premiums to have an absolute value less than 1) lower aggregate earnings. Unless the relationship of jobs to wages also has elasticity significantly less than zero (not supported by our data), there would not even be a rise in their number. The cut in Sunday wage premiums would primarily constitute a transfer of income from employees to business owners, with no offsetting increase in the number of employees. This is an important consideration, particularly as the FWC's mandate includes not only the employment and industry impacts of their wage decisions, but also explicitly the impact on the low-paid sector. The AWALI Survey found that more than half $(56.7 \%)$ of retail industry employees working 'anti-social' hours received premiums, and of these, almost a third (32\%) report relying on premiums to meet normal household expenses (Daly, 2014: 17).

Overall, the research supports the hypothesis that any response to a decrease in Sunday premiums is likely to take place via an adjustment of hours per employee, and not the number of employees. In this scenario, working more hours and experiencing greater disutility associated with working on Sundays, employees in the retail industry, many of whom are classified as low-paid, are likely to receive lower total earnings as a result. From the perspective of work-life balance policy, there is subsequently little evidence that in the tradeoff between wages and working at undesirable times, workers could be better off over all. The findings lend support to the idea that using premiums for unsociable hours is a reasonable way to enable compensation for people having to work those unsociable hoursotherwise, all the benefits flow to employers while increased costs (through lower utility arising from greater work-life interference) fall on employees. Whether it effectively reduces the amount of unsociable hours worked by employees is less clear, though international evidence suggests that this also happens. 


\section{References}

Angrist, Joshua D. and Jörn-Steffen Pischke. (2009). Mostly Harmless Econometrics, New York: Princeton University Press.

Atalay, Kadir and Garry Barrett. (2015). The Impact of Age Pension Eligibility Age on Retirement and Program Dependence: Evidence from an Australian Experiment. Review of Economics and Statistics. 97(1):71-87

Australian Bureau of Statistics. (2012a).Working Time Arrangements. Catalogue number 6342.0, November 2012, Canberra, Australia.

Australian Bureau of Statistics. (2012b). Employee Earnings and Hours. Catalogue number 6306.0, Canberra, Australia.

Australian Bureau of Statistics. (2014a). Employee Earnings and Hours. Catalogue number 6306.0, unpublished data, Canberra, Australia.

Australian Bureau of Statistics. (2014b). Forms of Employment. Catalogue number 6359.0, Canberra.

Australian Bureau of Statistics. (2015). Detailed Quarterly Labour Force Survey. Catalogue number 6291.0.55.003, February 2015, Table 05, Canberra, Australia.

Australian Industrial Relations Commission. (2008a). Exposure draft September 2008: Retail Industry Award 2010, September 12, 2008. Accessed at http://www.airc.gov.au/awardmod/databases/retail/Exposure/Retail exposure_draft.p df (March 2015).

Australian Industrial Relations Commission. (2008b). Procedure for carrying out award modernization Process. December 19, 2008. Accessed at http://www.airc.gov.au/awardmod/databases/retail/Decisions/2008aircfb1000.htm (March 2015).

Australian Industrial Relations Commission. (2009). Procedure for carrying out award modernization Process. AIRCFB 800, September 2, 2009. Accessed at http://www.airc.gov.au/awardmod/databases/trans_prov/Decisions/2009aircfb800.htm (March 2015).

Australian Industrial Relations Commission. (2010a). Retail industry comparison - Federal Awards - Wage Rates - Adults. Accessed at 
http://www.airc.gov.au/Awardmod/research/retail_industry/Wages_Adult_FED.xls

(March 2015)

Australian Industrial Relations Commission. (2010b). 'Retail industry comparison - Federal

Awards - Penalty Rates', Accessed at

http://www.airc.gov.au/Awardmod/research/retail_industry/PenaltyRates_FED.xls

(March 2015).

Australian Retailers Association. (2015). ' Productivity Commission Review of the Australian workplace relations system: Submissions on issues papers', Accessed at http://www.pc.gov.au/_data/assets/pdf_file/0010/189280/sub0217-workplacerelations.pdf (April, 2016).

David H. Autor (2003), 'Outsourcing at Will: The Contribution of Unjust Dismissal Doctrine to the Growth of Employment Outsourcing', Journal of Labor Economics 21(1): 1-42.

Baker, Angela, Sally Ferguson, and Drew Dawson. (2003). 'The perceived value of time: Controls versus shiftworkers', Time and Society, 12:27-39.

Besley, Timothy and Robin Burgess. (2004). 'Can labour regulation hinder economic performance? Evidence from India', The Quarterly Journal of Economics, 119: 91134.

Bittman, Michael. (2005). 'Sunday working and family time', Labour and Industry, 16: 5981.

Blundell, Richard and Monica Costa-Dias. (2009). Alternative approaches to evaluation in empirical microeconomics. Journal of Human Resources 44: 565-640.

Blundell, Richard and Thomas Macurdy. (1999). Labour supply: A review of alternative approaches. In Orley Ashenfelter and David Card (Eds.), Handbook of Labour Economics, Vol.III, pp.1559-1695. Amsterdam: Elsevier.

Borland, Jeff and Anthony Suen. (1990). The Ddeterminants of Individual Wages in Australia: Competitive and Non-Competitive Influences. Australian Economic Review, 23: 33-44.

Bourke, Latika. (2015). Malcolm Turnbull: Lower penalty rates inevitable with 'seven day economy'. Sydney Morning Herald. 6 October. http://www.smh.com.au/federalpolitics/political-news/malcolm-turnbull-lower-penalty-rates-inevitable-with-sevenday-economy-20151005-gk1yr5.html\#ixzz3uU1OOMrZ

Byron, Krista. (2005). A Meta-Analytic Review of Work-Family Conflict and Its Antecedents. Journal of Vocational Behavior, 67: 169-98. 
Card, David. (1992). Using regional variation in wages to measure the effects of the Federal minimum wage. Industrial and Labour Relations Review, 46: 22-37.

Cardoso, Ana R., Daniel S. Hamermesh and Jose Varejao. (2012). The timing of labour demand. Annals of Economics and Statistics, 105/106: 15-34.

Cook, Thomas D. and William. R Shadish. (1994). Social experiments: Some developments over the last fifteen years. Annual Review of Psychology, 45: 545-580.

Craig, Lyn and Judith E. Brown. (2014). Weekend work and leisure time with family and friends: Who misses out? Journal of Marriage and Family, 76: 710-727.

Daly, Tony. (2014). 'Evenings, nights and weekends: Working unsocial hours and penalty rates', Centre for Work and Life, University of South Australia, Adelaide. Accessed at http://www.unisa.edu.au/PageFiles/34117/PenaltyRatesReport_Oct2014\%20Final_R1 .pdf.

Dawkins, Peter. (1986). 'Non-standard hours of work and penalty rates in Australia', Journal of Industrial Relations, 27:329-349.

Deloitte Access Economics. (2015). 'The modern face of weekend work: Survey results and analysis', Canberra: Deloitte Touche Tohmatsu. Accessed at https://www.fwc.gov.au/documents/sites/awardsmodernfouryr/AM2014305-reportPGAandors-290515.pdf

Department of Education, Employment and Workplace Relations. (2008). Discussion Paper: National Employment Standards Exposure Draft, Canberra.

Department of Education, Employment and Workplace Relations. (2012). 'Submission to the Senate Standing Committee on Education, Employment and Workplace Relations Inquiry into Fair Work Amendment (Small Business: Penalty Rates Exemption) Bill 2012, Australian Government, Canberra.

Fernandez, Rosa M. and Christophe, J. Nordman. (2009). Are there pecuniary compensations for working conditions? Labour Economics, 16: 194-207.

French, Michael T. and Laura J. Dunlap. (1998). Compensating wage differentials for job stress. Applied Economics, 30: 1067-1075.

Ford, Michael T., Beth A. Heinen, and Krista L. Langkamer. (2007). Work and Family Satisfaction and Conflict: A Meta-Analysis of Cross-Domain Relations. Journal of Applied Psychology, 92: 57-80.

Greenhaus, Jeffrey H. \& Nicholas J. Beutell. (1985). Sources of Conflict between Work and Family Roles. Academy of Management Review, 10:76-88. 
Groot, Wim and Henriette Maassen van den Brink. (1999). The price of stress. Journal of Economic Psychology, 20: 83-103.

Hamermesh, Daniel S. (1999a). The timing of work over time, The Economic Journal, 109:37-66.

Hamermesh, Daniel S. (1999b). Changing inequality in markets for workplace amenities. The Quarterly Journal of Economics, 114:1085-1123.

Hamermesh, Daniel S. and Elena Stancanelli. (2014). Long workweeks and strange hours. National Bureau of Economic Research, Working paper No. 20449, Cambridge, Massachusetts. Retrieved from http://www.nber.org/papers/w20449.pdf , January 1, 2016.

Hamermesh, Daniel S. (2015). What's to know about time use? Journal of Economic Surveys, published online 31 March, 2015. doi: 10.1111/joes.12107

Hersch, Joni. (1998). Compensating differentials for gender-specific job injury risks. The American Economic Review, 88:598-607.

Hosking, Amanda and Mark Western. (2008). 'The effects of non-standard employment on work-family conflict', Journal of Sociology, 44: 5-27.

Kostiuk, Peter F. (1990). 'Compensating differentials for shift work', Journal of Political Economy, 98(5):1054-1075.

Lanfranchi, Joseph, Henry Ohlsson and Ali Skalli. (2002). 'Compensating wage differentials and shift work preferences', Economic Letters, 74:393-398.

Imbens, Guido. W. and Jeffrey M. Wooldridge. (2009). Recent developments in the econometrics of program evaluation. Journal of Economic Literature, 47: 5-86.

Jones, Sandra. (1981). 'Penalty rates under challenge', Journal of Industrial Relations, 23:504-507.

McCallum, Ron, Michael Moore and John Edwards. (2012).Towards more productive and equitable workplaces: An evaluation of the Fair Work legislation. Department of Education, Employment and Workplace Relations, Canberra. Accessed at https://docs.employment.gov.au/documents/towards-more-productive-and-equitableworkplaces-evaluation-fair-work-legislation (November 2015)

Michel, Jesse S., Jacqueline K. Mitchelson, Shaun Pichler and Kristin L.Cullen. (2010). Clarifying relationships among work and family social support, stressors, and workfamily conflict. Journal of Vocational Behavior, 76: 91-104.

National Competition Council. (2002).Second tranche assessment of governments' progress with implementing National Competition Policy and related reforms: Vol. I, 30 June 
1999', Commonwealth of Australia, Canberra. Accessed at

http://ncp.ncc.gov.au/docs/Second\%20tranche\%20assessment\%20vol\%201\%201999. pdf (April 2015).

New South Wales Government. (2007). Reform of Shop Trading Hours in New South Wales:

Part 4 of the Shops and Industries Act 1962. Better Regulation Office Issues Paper,

August 2007. Accessed at http://pandora.nla.gov.au/pan/83604/20080422-

1426/www.dpc.nsw.gov.au/_data/assets/pdf_file/0016/12643/BRO_website -

Issues_Paper_-_Trading_Hours___230807.pdf (April 2015).

Nisen, Max. (2014) The rise of robot scheduling is a nightmare for low wage workers.

Available at: http://qz.com/249582/the-rise-of-robot-scheduling-is-a-nightmare-forlow-wage-workers/.

Peetz, David, Keith Townsend, Bob Russell, et al. (2003). Race Against Time: Extended Hours in Australia. Australian Bulletin of Labour 29: 126-142.

Pocock, Barbara, Natalie Skinner and Sandra Pisaniello. (2010). How much should we work?

Working hours, holidays and working life: the participation challenge. Adelaide:

Centre for Work + Life, University of South Australia.

Preston, Alison. (1997). ' Where are we now with human capital theory in Australia?', The Economic Record, 73:51-78.

Rosen, Sherwin. (1986). 'The theory of equalizing differences', in Ashenfelter, Orley \& Richard Layard, eds, Handbook of Labour Economics, North-Holland, Amsterdam.

Scheffel, Juliane. (2011). Compensation of unusual working schedules. SFB 649 Discussion paper, No. 2011-026, Berlin. Retrieved from http://www.econstor.eu/bitstream/10419/56696/1/661168670.pdf , January 1, 2016.

Schor, Juliet B. (1998) The Overspent American: Why we want what we don't need, New York: Basic Books.

Skinner, Natalie, Claire Hutchinson \& Barbara Pocock. (2012). 'The big squeeze: Work, life and care in 2012 - The Australian Work and Life Index', Centre for Work and Life, University of South Australia, Adelaide.

Skinner, Natalie and Barbara Pocock. (2014). 'The persistent challenge: Living, working and caring in 2014 - The Australian Work and Life Index', Centre for Work and Life, University of South Australia, Adelaide.

Wright, Sally and John Buchanan. (2013). Award reliance, Fair Work Commission, Research Report 6/2013, Accessed at 
https://www.fwc.gov.au/documents/sites/wagereview2014/research/report6.pdf (March 2015).

Yuen, Kelvin, David Rozenbes and Samantha Farmakis-Gamboni. (2015). Award reliance and business size: A data profile using the Australian Workplace Relations Study. Fair Work Commission, Research Report 1/2015, Accessed at https://www.fwc.gov.au/documents/sites/wagereview2015/research/Award_reliance business_size_27_Feb.pdf(March 2015). 
Table 1. Changes to retail industry award conditions in NSW and Victoria ${ }^{(a)}$

\begin{tabular}{|c|c|c|c|c|c|c|c|c|c|}
\hline Period & Award & $\begin{array}{c}\text { Sunday } \\
\text { premium }\end{array}$ & $\begin{array}{c}\text { Saturday } \\
\text { premium }\end{array}$ & $\begin{array}{c}\text { Night } \\
\text { shift }\end{array}$ & $\begin{array}{c}\text { Evening } \\
\text { shift }\end{array}$ & $\begin{array}{c}\text { Public } \\
\text { holiday }\end{array}$ & Casual & Overtime & $\begin{array}{c}\text { Base } \\
\text { hourly } \\
\text { rate }\end{array}$ \\
\hline Before & $\begin{array}{c}\text { NSW: Shop } \\
\text { Employees Award }\end{array}$ & $150 \%$ & $125 \%$ & $130 \%$ & $117.5 \%$ & $250 \%$ & $115 \%$ & $\begin{array}{c}150 \% \text { first } \\
\text { three } \\
\text { hours; then } \\
200 \%\end{array}$ & 15.34 \\
\hline Before & $\begin{array}{c}\text { Victoria: } \\
\text { Interim Award } \\
2000\end{array}$ & $200 \%$ & $133 \%{ }^{(\mathrm{c})}$ & $130 \%$ & $125 \%$ & $250 \%$ & $125 \%$ & $\begin{array}{c}150 \% \text { first } \\
\text { three } \\
\text { hours; then } \\
200 \%\end{array}$ & 15.86 \\
\hline After & $\begin{array}{c}\text { Modern Award: } \\
\text { General Retail } \\
\text { Industry Award } \\
\mathbf{2 0 1 0}\end{array}$ & $200 \%$ & $125 \%$ & $130 \%$ & $125 \%$ & $250 \%$ & $125 \%$ & $\begin{array}{c}150 \% \text { first } \\
\text { three } \\
\text { hours; then } \\
200 \%\end{array}$ & 15.78 \\
\hline
\end{tabular}

(a) For an adult, full-time employee

(b) The base hourly rate is for an adult, full time, entry level retail services worker. The rate is as at the end of 2008, at the time the draft General Retail Award was released.

(c) Saturday premiums in Victoria varied by classification. These have been averaged. A full break down is provided in a data appendix available from the authors.

Source: Australian Industrial Relations Commission (2010a, 2010b), General Retail Award 2010 
Table 2. Annual changes in employment

\begin{tabular}{c|c|c|cc}
\hline \multirow{2}{*}{ Year } & \multicolumn{2}{|c|}{$\begin{array}{c}\text { Annual \% change in } \\
\text { total employed }\end{array}$} & \multicolumn{2}{c}{$\begin{array}{c}\text { Annual \% change in } \\
\text { hours per employee }\end{array}$} \\
\cline { 2 - 5 } 2001 & NSW & Victoria & NSW & Victoria \\
2002 & 5.5 & 3.7 & -0.2 & -4.9 \\
2003 & -1.2 & 4.4 & 3.9 & -0.7 \\
2004 & 13.2 & 6.3 & -5.9 & 2.0 \\
2005 & -5.2 & -10.0 & -0.5 & 0.0 \\
2006 & 8.3 & 10.3 & 4.6 & 2.5 \\
2007 & -2.8 & -0.4 & -3.2 & -5.5 \\
2008 & -6.6 & -0.4 & 0.2 & 2.5 \\
2009 & 19.8 & 1.5 & 2.0 & -4.0 \\
2010 & -8.0 & -1.7 & -2.9 & 3.3 \\
2011 & -8.8 & 6.5 & 0.8 & 1.1 \\
2012 & 7.3 & 0.7 & -2.1 & 0.1 \\
2013 & -1.8 & 1.2 & -1.8 & -5.2 \\
2014 & 8.5 & -2.7 & 4.6 & -0.4 \\
\hline \multirow{2}{*}{200} & -9.3 & 6.8 & -3.9 & 0.9 \\
\hline Average pre-2008 & 3.9 & 1.9 & 0.1 & -1.0 \\
\hline & -2.0 & 1.8 & -0.9 & 0.0 \\
\hline
\end{tabular}


Table 3. Wage effects for retail employees in NSW and Victoria

\begin{tabular}{|c|c|c|c|c|c|c|}
\hline \multirow[b]{2}{*}{ Hourly wage } & \multicolumn{3}{|c|}{ Sunday workers } & \multicolumn{3}{|c|}{ Non Sunday workers } \\
\hline & $\begin{array}{c}\text { Pre- } \\
\text { announce- } \\
\text { ment }\end{array}$ & $\begin{array}{c}\text { Post- } \\
\text { announce- } \\
\text { ment }\end{array}$ & Change & $\begin{array}{c}\text { Pre- } \\
\text { announce- } \\
\text { ment }\end{array}$ & $\begin{array}{c}\text { Post- } \\
\text { announce- } \\
\text { ment }\end{array}$ & Change \\
\hline \multicolumn{7}{|l|}{ Mean } \\
\hline NSW & 15.85 & 20.41 & 4.56 & 19.23 & 21.00 & 1.76 \\
\hline Victoria & 16.29 & 20.09 & 3.80 & 19.22 & 20.67 & 1.45 \\
\hline$\%$ difference & -2.72 & 1.57 & 4.29 & 0.07 & 1.59 & 1.52 \\
\hline \multicolumn{7}{|l|}{ Median } \\
\hline NSW & 13.98 & 19.18 & 5.20 & 17.39 & 19.74 & 2.34 \\
\hline Victoria & 16.95 & 19.29 & 2.34 & 17.00 & 19.34 & 2.34 \\
\hline$\%$ difference & -17.50 & -0.58 & 16.92 & 2.31 & 2.07 & -0.24 \\
\hline \multicolumn{7}{|l|}{$\mathrm{n}$} \\
\hline NSW & 112 & 295 & & 328 & 980 & \\
\hline Victoria & 95 & 259 & & 330 & 976 & \\
\hline Diff-in-Diff & \multicolumn{2}{|c|}{0.095} & & \multicolumn{2}{|c|}{0.010} & \\
\hline (Std. Err) & \multicolumn{2}{|c|}{$(0.093)$} & & \multicolumn{2}{|c|}{$(0.050)$} & \\
\hline
\end{tabular}


Table 4. Sample means on NSW and Victorian retail employees in HILDA, pooled

\begin{tabular}{|c|c|c|c|c|}
\hline \multirow[b]{2}{*}{ Characteristic } & \multicolumn{2}{|c|}{ Before } & \multicolumn{2}{|c|}{ After } \\
\hline & NSW & Victoria & NSW & Victoria \\
\hline Female & 57.4 & 52.2 & 61.7 & 57.3 \\
\hline Mean age & 32.1 & 32.5 & 32.5 & 32.7 \\
\hline Under 25 years old $(\%)$ & 44.4 & 40.3 & 44.1 & 38.3 \\
\hline Non-English speaking background & 8.3 & 8.2 & 9.3 & 7.5 \\
\hline Married or defacto $(\%)$ & 37.6 & 39.8 & 37.1 & 35.4 \\
\hline Living in metropolitan area $(\%)$ & 62.2 & 66.5 & 66.3 & 68.1 \\
\hline Full time student (\%) & 25.5 & 25.8 & 22.9 & 23.5 \\
\hline \multicolumn{5}{|l|}{ Education level (\%) } \\
\hline Degree or higher & 8.9 & 9.5 & 10.4 & 13.0 \\
\hline Completed Year 12 & 49.1 & 52.6 & 57.1 & 58.2 \\
\hline Year 11 or below & 42.0 & 37.9 & 32.5 & 28.9 \\
\hline Mean weekly hours & 29.1 & 29.4 & 28.8 & 29.4 \\
\hline Employed part time (\%) & 55.8 & 52.4 & 57.9 & 54.5 \\
\hline Employed on casual basis (\%) & 45.0 & 38.9 & 41.3 & 35.4 \\
\hline Union member $(\%)$ & 16.3 & 14.5 & 20.2 & 14.5 \\
\hline \multicolumn{5}{|l|}{ Workplace size (\%) } \\
\hline Small (less than 20 employees) & 9.9 & 6.6 & 6.0 & 6.3 \\
\hline Medium (20 to 99 employees) & 14.4 & 6.0 & 10.9 & 10.7 \\
\hline Large (100 or more employees) & 75.7 & 87.4 & 83.1 & 83.0 \\
\hline Usually works on Sunday (\%) & 25.3 & 22.7 & 23.7 & 20.6 \\
\hline Number of observations & 742 & 686 & 1167 & 1119 \\
\hline Number of individuals & 433 & 392 & 393 & 354 \\
\hline
\end{tabular}


Table 5. Employment effects

\begin{tabular}{|c|c|c|c|c|}
\hline \multirow{2}{*}{ Variable } & \multicolumn{2}{|c|}{ Number of employees } & \multicolumn{2}{|c|}{ Hours per employee } \\
\hline & Est. & Std. Err & Est. & Std. Err \\
\hline after $19 / 12 / 2006$ & -0.001 & $(0.037)$ & 0.005 & $(0.021)$ \\
\hline after19/12/2007 & 0.008 & $(0.037)$ & 0.009 & $(0.016)$ \\
\hline after 19/12/2008 (Announcement date) & -0.059 & $(0.050)$ & $-0.052 * *$ & $(0.021)$ \\
\hline after 1/7/2010 (First increase) & -0.055 & $(0.034)$ & 0.025 & $(0.015)$ \\
\hline after $1 / 7 / 2011$ & $0.051^{*}$ & $(0.029)$ & -0.010 & $(0.019)$ \\
\hline after $1 / 7 / 2012$ & -0.043 & $(0.048)$ & -0.034 & $(0.028)$ \\
\hline after $1 / 7 / 2013$ & -0.003 & $(0.049)$ & 0.001 & $(0.014)$ \\
\hline after $1 / 7 / 2014$ & -0.016 & $(0.029)$ & $-0.029 *$ & $(0.016)$ \\
\hline State (NSW) effects & $0.415^{*}$ & $(0.237)$ & $0.328^{* *}$ & $(0.149)$ \\
\hline State-specific trend effects & 0.000 & $(0.002)$ & -0.002 & $(0.001)$ \\
\hline Employment to population ratio & 0.019 & $(0.021)$ & $0.024 *$ & $(0.014)$ \\
\hline Youth employment to population ratio & 0.006 & $(0.005)$ & -0.002 & $(0.005)$ \\
\hline Unemployment rate & 0.005 & $(0.014)$ & $0.018^{*}$ & $(0.010)$ \\
\hline Youth unemployment rate & 0.000 & $(0.005)$ & $0.006^{* *}$ & $(0.003)$ \\
\hline State retail sales & -0.382 & $(0.402)$ & $0.660 * *$ & $(0.309)$ \\
\hline $\mathrm{n}$ & \multicolumn{2}{|c|}{114} & \multicolumn{2}{|c|}{114} \\
\hline $\begin{array}{l}\text { Cumulative post-announcement effects (p- } \\
\text { value) }\end{array}$ & \multicolumn{2}{|c|}{0.079} & \multicolumn{2}{|c|}{0.027} \\
\hline $\begin{array}{l}\text { Cumulative post-implementation effects (p- } \\
\text { value) }\end{array}$ & \multicolumn{2}{|c|}{0.176} & \multicolumn{2}{|c|}{0.180} \\
\hline Test for lead effects ( $\mathrm{p}$-value) & \multicolumn{2}{|c|}{0.848} & \multicolumn{2}{|c|}{0.413} \\
\hline
\end{tabular}

$\overline{\text { Heteroskedastic and autocorrelation-consistent standard errors in parentheses. Statistical significance: } * * *} \mathrm{p}<0.01, * *$ $\mathrm{p}<0.05,{ }^{*} \mathrm{p}<0.1$. 
Table 6. Effects on the probability of working on Sundays

\begin{tabular}{|c|c|c|c|c|c|c|c|c|}
\hline \multirow[t]{3}{*}{ Variable } & \multicolumn{6}{|c|}{ Probability of working Sundays } & \multirow{2}{*}{\multicolumn{2}{|c|}{$\begin{array}{c}\text { Placebo: } \mathrm{Pr} \\
\text { (Working Saturdays) }\end{array}$}} \\
\hline & \multicolumn{2}{|c|}{ Model 1} & \multicolumn{2}{|c|}{ Model 2} & \multicolumn{2}{|c|}{ Model 3} & & \\
\hline & Est. & Std. Err & Est. & $\begin{array}{l}\text { Std. } \\
\text { Err }\end{array}$ & Est. & Std. Err & Est. & $\begin{array}{l}\text { Std. } \\
\text { Err }\end{array}$ \\
\hline after 19/12/2008 (Announcement) & 0.041 & $(0.043)$ & 0.034 & $(0.042)$ & 0.032 & $(0.053)$ & 0.003 & $(0.058)$ \\
\hline after 1/7/2010 (First increase) & -0.001 & $(0.045)$ & 0.001 & $(0.044)$ & 0.017 & $(0.058)$ & 0.083 & $(0.063)$ \\
\hline after $1 / 7 / 2011$ & $-0.094 * *$ & $(0.044)$ & $-0.091 * *$ & $(0.044)$ & -0.079 & $(0.057)$ & 0.005 & $(0.061)$ \\
\hline after $1 / 7 / 2012$ & 0.046 & $(0.039)$ & 0.056 & $(0.039)$ & $0.082 *$ & $(0.049)$ & 0.010 & $(0.055)$ \\
\hline after $1 / 7 / 2013$ & 0.017 & $(0.042)$ & 0.015 & $(0.041)$ & -0.032 & $(0.052)$ & -0.064 & $(0.055)$ \\
\hline \multicolumn{9}{|l|}{ Demographic controls } \\
\hline Less than 25 years old & & & $0.145^{* * *}$ & $(0.023)$ & $0.188 * * *$ & $(0.025)$ & $0.179 * * *$ & $(0.029)$ \\
\hline Gender (Female) & & & 0.022 & $(0.019)$ & 0.015 & $(0.021)$ & $-0.051 * *$ & $(0.025)$ \\
\hline Married or de facto & & & -0.012 & $(0.024)$ & -0.018 & $(0.028)$ & 0.018 & $(0.033)$ \\
\hline Number of dependent children & & & $-0.019 *$ & $(0.010)$ & -0.015 & $(0.012)$ & -0.007 & $(0.015)$ \\
\hline Year 11 or below education & & & -0.014 & $(0.031)$ & 0.007 & & 0.048 & $(0.041)$ \\
\hline \multicolumn{9}{|l|}{ Workplace/ employment controls } \\
\hline Large employer & & & & & 0.041 & $(0.042)$ & $-0.133 * *$ & $(0.054)$ \\
\hline Union member & & & & & 0.024 & $(0.027)$ & $-0.057 * *$ & $(0.028)$ \\
\hline State (NSW) effects & 0.029 & $(0.032)$ & 0.020 & $(0.030)$ & -0.006 & $(0.036)$ & -0.042 & $(0.042)$ \\
\hline No. observations & \multirow{2}{*}{\multicolumn{2}{|c|}{$\begin{array}{c}3714 \\
0.8488\end{array}$}} & \multirow{2}{*}{\multicolumn{2}{|c|}{$\begin{array}{c}3714 \\
0.7346\end{array}$}} & \multirow{2}{*}{\multicolumn{2}{|c|}{$\begin{array}{c}2505 \\
0.7215 \\
\end{array}$}} & \multirow{2}{*}{\multicolumn{2}{|c|}{$\begin{array}{c}2505 \\
0.5503 \\
\end{array}$}} \\
\hline Cumulative effects (p-value) & & & & & & & & \\
\hline
\end{tabular}

Cluster-robust standard errors in parentheses. Statistical significance: ${ }^{* * *} p<0.01,{ }^{* *} p<0.05,{ }^{*} p<0.1$. 